\title{
Vast vicinity: learning from essential settling and dwelling
}

\author{
H. Göritz \\ HansjörgGöritzArchitekturstudio, Hannover - Berlin, Germany \\ College of Architecture + Design, University of Tennessee, USA
}

\begin{abstract}
'Sustainability' is the word of our time. 'Sprawl' is a problem of our time [1]. Apparently, given its full extent, housing based on individualistic image still sells better than rare sense for design appropriately fit to context and task. Thus, the notion of 'dwelling and settling' has extreme negative impact on the relationships between urban, rural, garden and house. Accounting for populist aesthetics, value-price-confusion, and prevailing land politics, the trivial and contradictory questions of principle remain: 'rural or urban?' - 'garden or house?' This paper explains an architectural research on the symbiotic propositions of settling with 'houses as gardens'. Working with the idea of 'as-well-as' instead of 'either-or' is a cardinal principle of this approach. The principle 'from the part to the entirety' is what defines these designs as 'urban modules', which have the potential to generate a truly coherent mosaic that constitutes a different settlement pattern that proposes an urban as well as rural future. It holds the promise of a way of settling and dwelling that is truly 'enduring'.
\end{abstract}

Keywords: sub-urban sprawl, rural, settling, housing, contextualism, urban ecology, urban modules, courtyard houses, open plan, urban-garden-houses

\section{Introduction}

'Dwelling' always reminds me of 'Walden'. Henry David Thoreau subtitled the original American 1854 edition as 'or, Life in the Woods' [2]. For his 'experiment', the Yankee had withdrawn to a self-timbered cabin on lonely Walden Pond for two and a half years and must therefore have known his subject well. Among other things, it becomes evident that 'Walden' is 


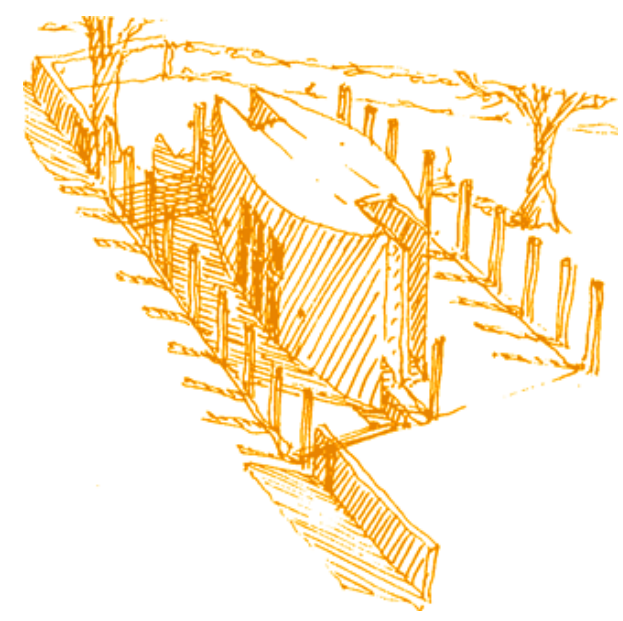

Figure 1: Concept Sketch 'Served Space and Servant Core' [Author] Extroverted space as open periphery to a central volume 'Stone House within a Timber House', Trennemoor Residence, Kirchhorst, Germany 1990 - 1992

synonymous with 'living'. Long before the slogan of a clever Scandinavian furniture company [3], the analogy had already arisen whereby 'dwelling' is a special form of life, that is to say, life shaped, brought into form.

The strongest connection between life and form occurs with the most elementary characteristics of living in the forest, the mountains or at the sea. Certainly there are other reasons for seeking out such an unusual life than just the calm and the fresh air, and for connecting that life to these schemes of house. It is certain, too, that the former teacher and later surveyor Thoreau is seen from today's romantic perspective as an early freak or even as a purist, since life in those days was 'minimal' by modern standards anyway.

Groups like the Shakers cultivated this austere normality as a matter of course, and the 'Primitive Hut' by the time it was formulated by the Jesuit Abbot Laugier in Europe [4], had long been inherent in American wooden houses. Thus Thoreau's basic motive goes further or deeper than this cultivation of the everyday; he seeks the way to genuine liberty. However, it was the unromantic and almost scientific meticulousness of his dwelling-living-experiment that impressed me deeply in the mid-eighties.

\section{Paradigms: essentials sophisticated}

'Walden' certainly was an experiment at minimizing consumption back then. Thus moving on, learning valuable lessons from contemporary housing 


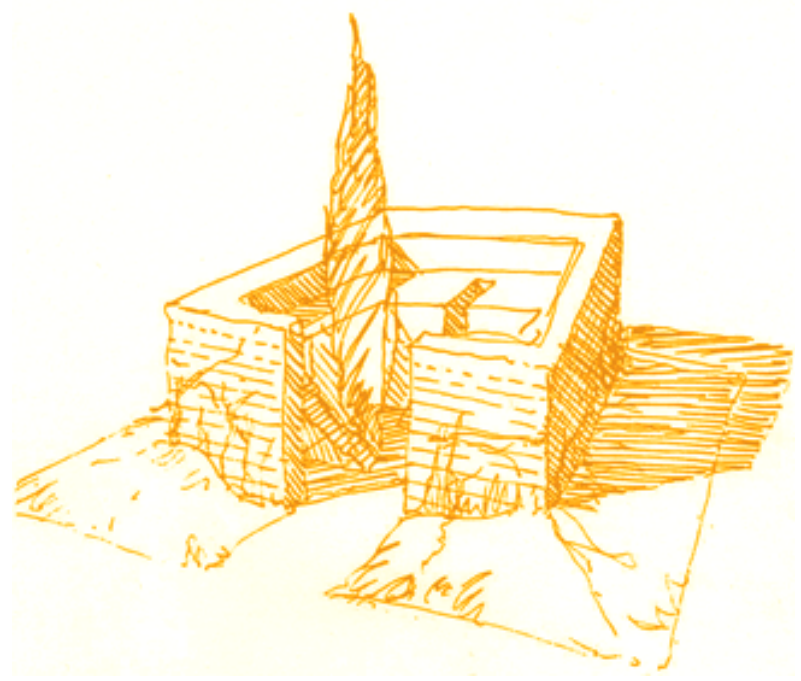

Figure 2: Concept Sketch 'Monolithic Module' [Author]

Introverted space as volumetric periphery to an open central void 'Hall within a Stone Block', Horstkotte Residence, Hannover, Germany 1991 - 1993

propositions, each indicating a searching beyond: dense, austere, serene, or experimental, can evoke alternatives to our current misunderstood assemblage of 'traditionalism / modernism / technologism'. The possibility emerging is for both 'traditional and modern' as an impetus, serving as a hallmark of ageless essential thinking. That is little to be invented, a lot to be re-dis-covered, as work that favours the ken of the proved, translated into contemporary purposes, which might also carry on solutions of timeless validity. All that is what could exemplify architecture's break with the idolitrous golden calf of 'primitive stylehuts'.

Soon after my acquaintance with Thoreau's work, I stumbled upon a Japanese dwelling-box: Shigeru Uchida's 'U-Atelier' has stood in the forest at Lake Yamanakako since 1974 [5]. It is nothing but a box of untreated lauan pine. Abstracted, 'abstrahere' [lat], distilled, withdrawn. All that remains are the essentials: sleeping-place and eating-place with a fire-place in between. These are prefigurations of purposes within the prefiguration of a dwelling, but they are also more than just pure spiritualization that radically demands the energy for a precise, plain life. Rather, the U-Atelier is a timeless example of elementary abstraction of the banal, quotidian in the word's best sense and opposed to the trivial, as well as an experiment and prototype for a home [6]. However, it is exactly this definitiveness that separates Uchida's experiment conclusively from the trivialities of the banal in their most concrete sense. 

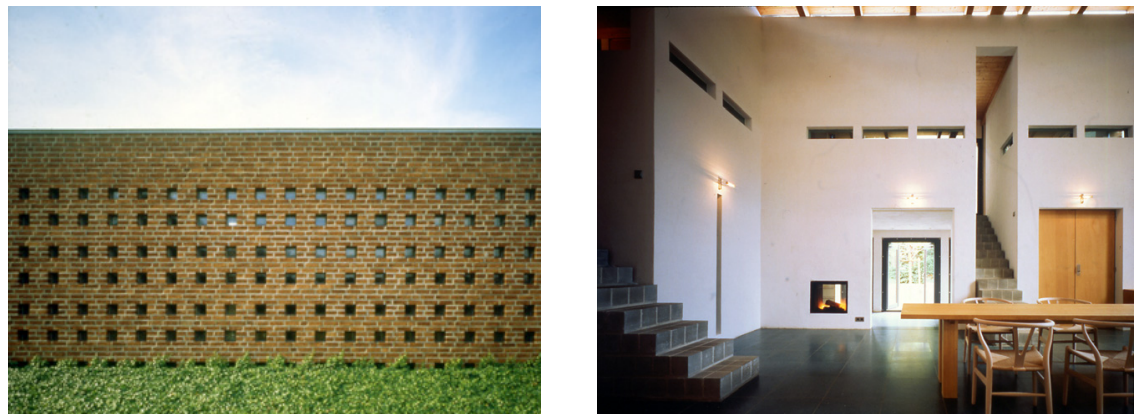

Figure 3: 'Hall within a Stone Block', Horstkotte Residence, Hannover, Germany 1991 - 1993 [Author]

In 1975 - 1976, Tadao Ando's 'Azuma House' continued this search, but left the forest to be implanted manifest in the suburban jungle of Sumiyoshi, Osaka [7]. In addition to Uchida's materiality of elements as described, Ando introduces the significance of daylight into the totality of an enclave. The concrete succinct austerity of the house's absolute essentiality appeared in Europe for the first time a decade after the Azuma House in 1986 at London's 9H Gallery, at one of Ando's first exhibitions that brought his approach to the attention of the western world as an approach beyond postmodernism [8]. Two more decades would eventually be required for this approach to be known and to be deeply comprehended as an -ism, a doctrine, and as minimalism in the day-to-day workings of all corners of the field. Thoreau, the Shakers, the Cistercians, and others before and after them show us that 'habitare' [lat], to live, to dwell, is always the central issue of building, an activity whose purpose before all others is to protect and to provide shelter. This elementary work with concepts of dwelling is therefore a recurring, timeless 'exploration of the essential', and it is this that makes 'building as physical expression' a particular kind of being.
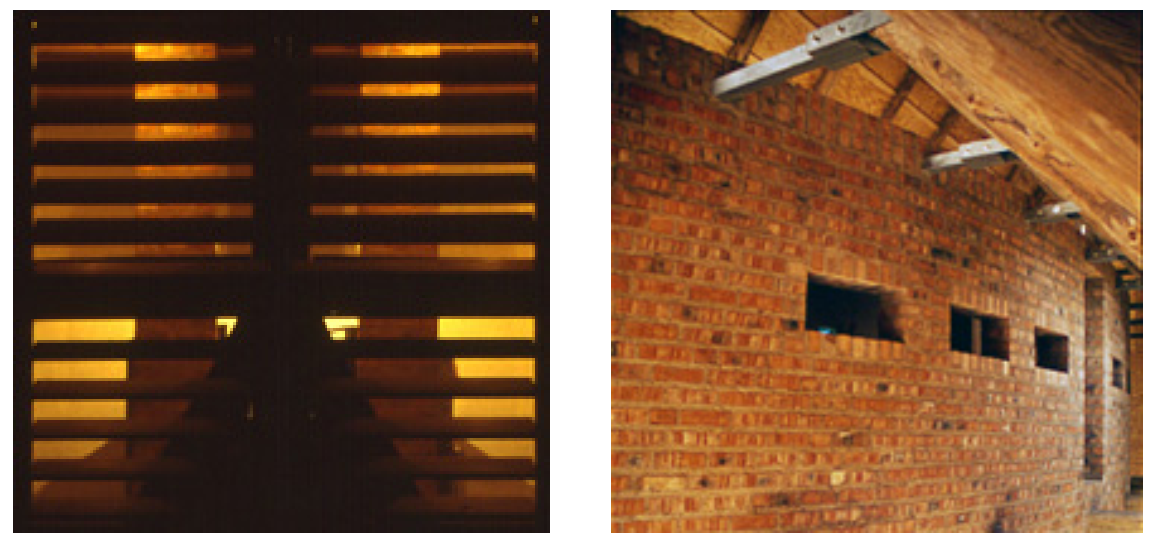

Figure 4: 'Stone House within a Timber House', Trennemoor Residence, Hannover. Germanv 1992 [Author〕 


\section{Values: expression of complex reason}

Why does the essential succeed but seldom, and that usually only in hermitage, on holiday or as a manifesto? To achieve adequate stature in an aesthetically over-diversified world, the penetration of the resulting heterogeneity is likewise an oversized effort. The effort is worth the quality of life to be gained. The Shakers lived and acted consistently on the principle of producing nothing unsuited to use, but also did not hesitate to do this in a beautiful way [9]. And Donald Judd indicated minimalism as 'the simple expression of complex thought'.

Thus the importance of education to develop conscious being becomes evident. Not in the academic sense, but rather in the sense of self-cultivation, or better: development, perfection. By oneself, autodidactically. To recognize the essential is to be intelligent, 'interlegere' [lat], recognizing hidden meaning, distinguishing, differentiating, reasoning, estimating. Only then can one be capable of cultivating and fostering what can be deemed essential and serviceable to our lives, to differentiate and be uncompromising about it.

From this perspective, the question can no longer be the habitual one, about how at all one can stand to live in the beauty of absolute essentiality, but rather its converse, that is how one deliberately wants to live. Only from that question will the beauty of dwelling and living result.

This consciously differentiated choice constrains the originating of spaces and objects to emerge in such a way that they correspond with the choice of how to live and facilitate the way of as essential life. As a quality of experience, of silent and inconspicuous character, in its painstaking absence of uselessness, space consequently arises for the opulence of the simple.

In the Shinto culture of Zen, immense simplicity and complex meaning form an inseparable unity. Transferred, this implies that neutrally open spatial configurations allow for any conceivable adaptation. Servant volumes disposed in such spaces become existential void-columns, structuring and organizing this

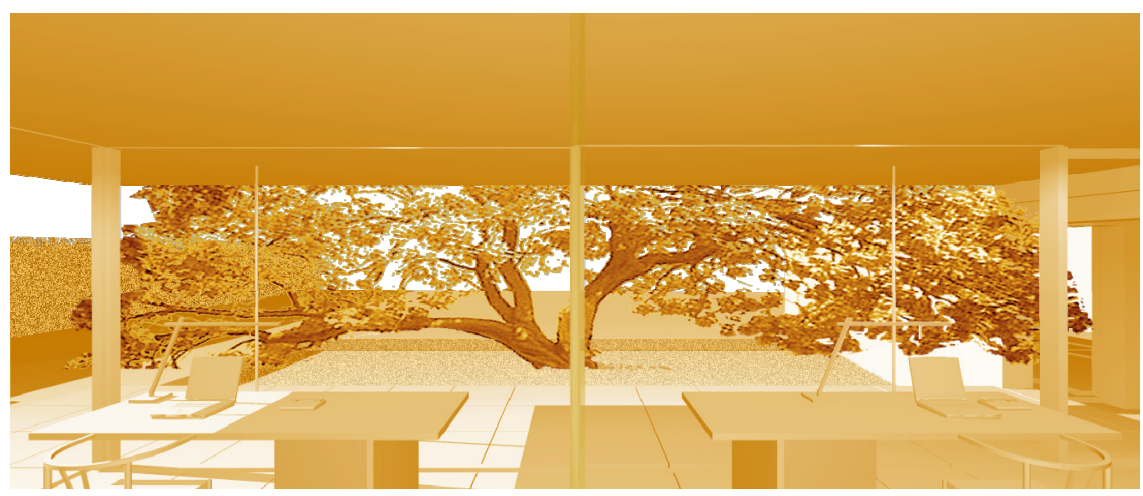

Figure 5: 'A House is a Garden is a House...' B-E Residence, Isernhagen, Germany 2005 - 2006 [Author] 
neutrality for any practical use according to individual perception of life. Suddenly and long after Katsura [10], even open, prosaic studio flats become an unobstructed and at the same time sophisticated context for the important facets of life, like a kind of 'New Lofts'. Inhibiting and obscuring elements are cleared out and straightened up by means of deliberate providing and appropriating. In one of his early essays, Ando described such juxtapositions as 'Representation and Abstraction' [11], as spatial phenomena enriching our architectural apperception.
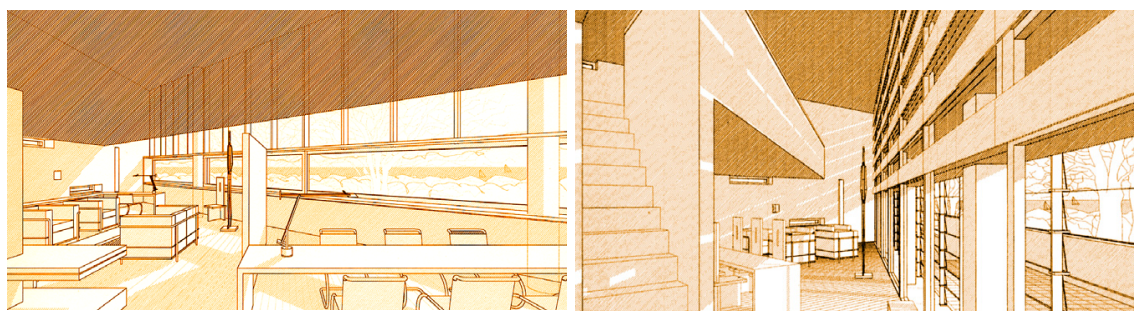

Figure 6: 'Maschsee New Lofts', Hannover Germany 1999 - 2000 [Author]

We must face the causality that real existing internal ratios do correspond with de facto internal circumstances of living. Furthermore, since everything is an external expression of internal sensitivities, and since these contemporary expressions are plainly unauthentic, we simply end up at nothing but pastiches of internal spaces that then again effect external spaces to enormous extent: urban, settlement and landscape spaces, and the ratios of this conditionality perpetuate themselves over and over again - with a fatal logic.
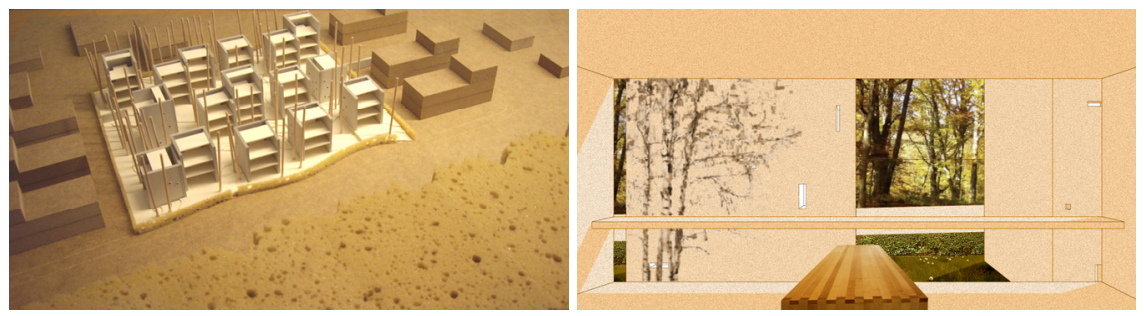

Figure 7: 'Waldersee New Lofts', Hannover, Germany 2003 [Collaboration Göritz + Despang Architekten]

\section{Strategies: modules for encompassing reason}

Mode of dwelling has the highest degree of impact on both sub-urban and ruralurban-garden-house. Even accounting for disastrous anti-urban sprawl of spatial relations and behind the global confusion of value and price in vulgar capitalist 


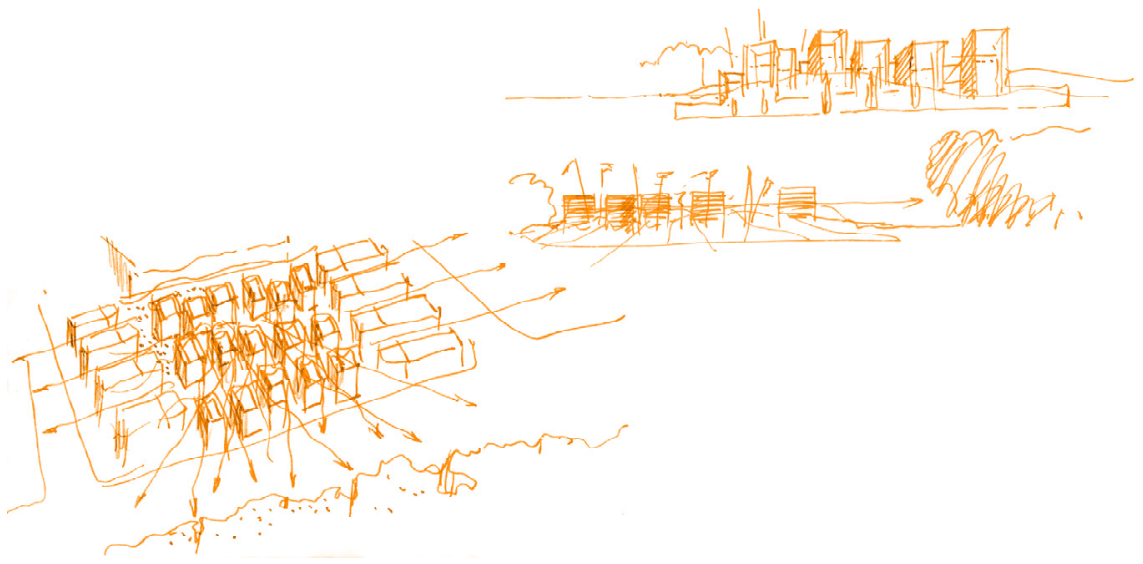

Figure 8: Concept Sketch 'Tight + Light', 'Waldersee New Lofts', Hannover, Germany 2003 [Author]

land politics, there are still the same simple contradictory questions of principle: 'rural or urban?' - 'garden or house?' Couldn't the contribution consist of symbiosis - building 'houses as gardens' in cities and settlements? Working 'aswell-as' instead of 'either-or' would become a cardinal principle of this approach. The inversion of the principle 'from the part to the entirety' is what defines 'urban modules'.

The requirements and advantages of 'suburban townhouses' such as Mies' courtyard houses of the thirties [12] and Utzon's Kingo and Fredensborg settlements of the fifties and sixties [13] serve as paradigms of urban types and densities with a new interplay between living quarters and privacy, exterior and interior relations and spaces.

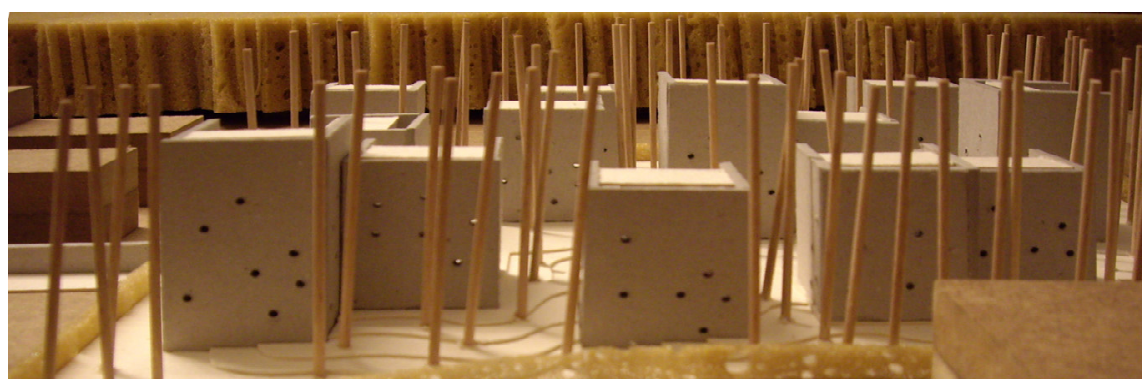

Figure 9: Concept Model 'Tower Models + Par', 'Waldersee New Loft', Hannover, Germany 2003 [Göritz + Despang Architekten] 
346 Sustainable Development and Planning IV, Vol. 1
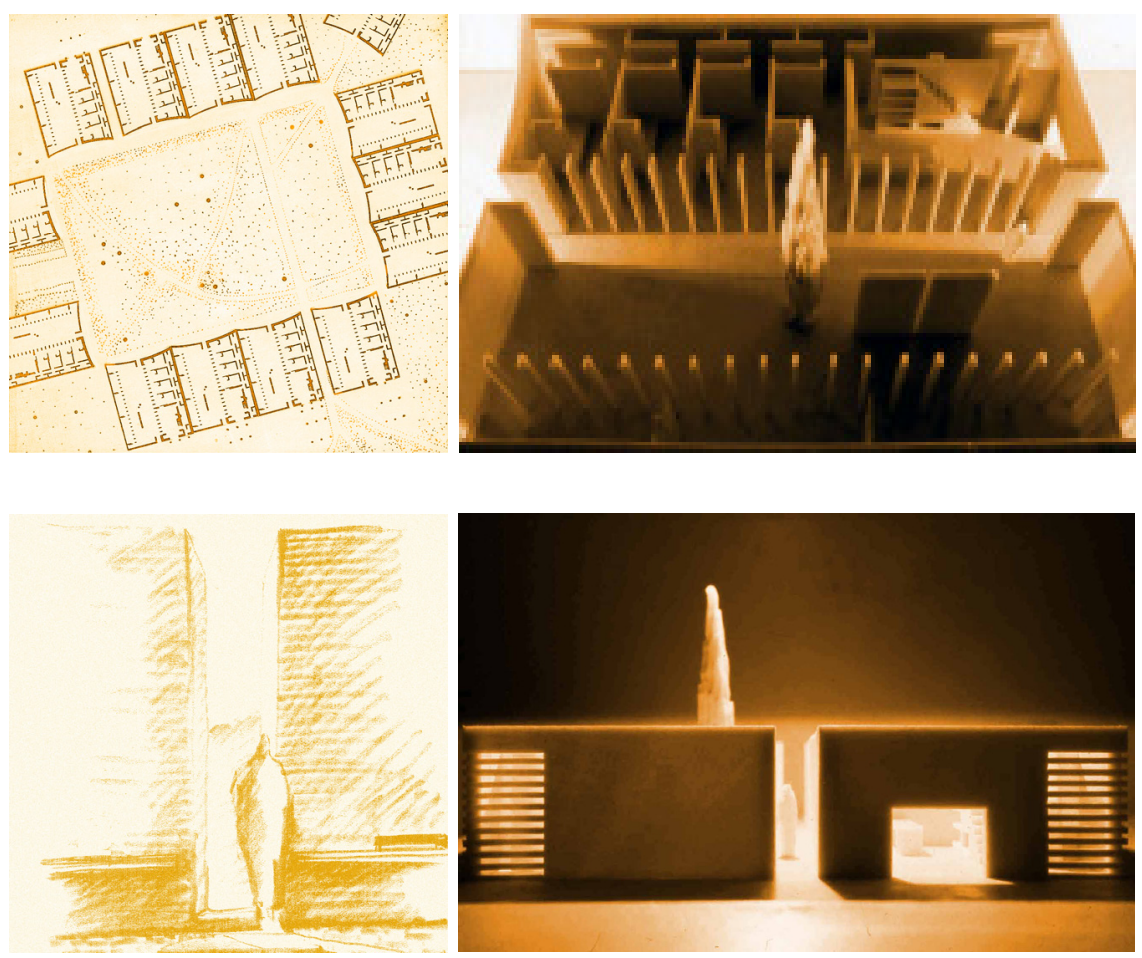

Figure 10: 'Hortus Conclusus', G-Residence Concept 'Urban Carpet Module', Hannover, Germany 1993 - 1994 [Author]
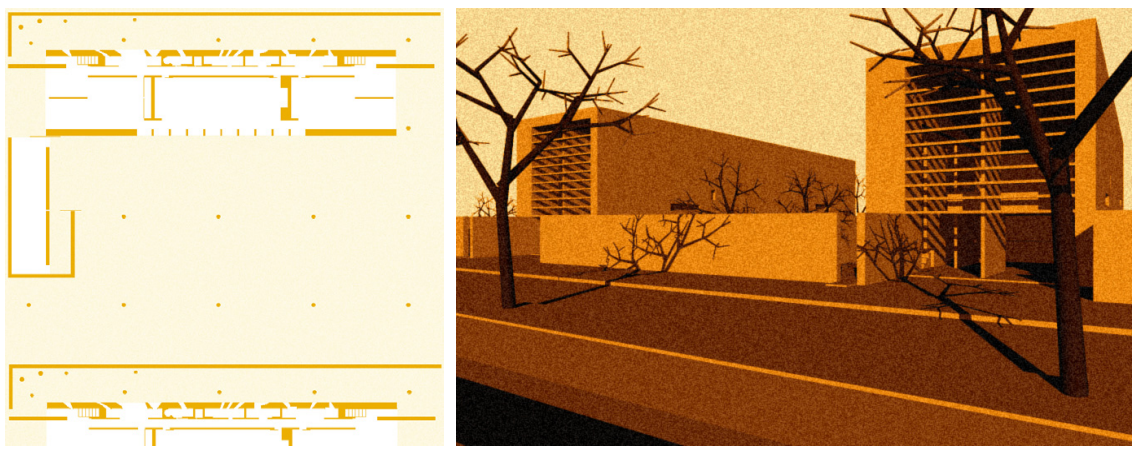

Figure 11: 'Seelhorst Gardens', Monospace-Residences Concept 'Urbain Chain Modules' Hannover, Germany 1996 [Author] 


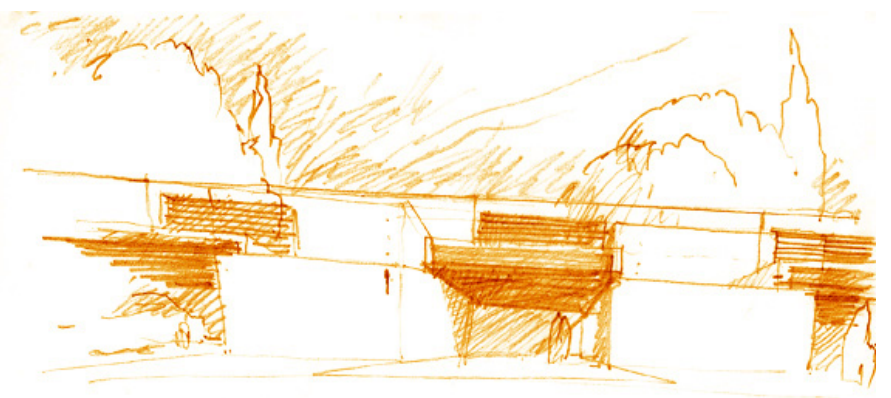

Figure 12: 'New Urban-Garden-Houses', Exterior Sketch 'Urban Modules' Osnabrueck Germany 2004 - 2005 [Author]

Thus the 'urban module' suites and serves in a simple yet complex way to create the collective renewal of basic hybrids or transitional spaces for dialectics within urban quarters. By means of enclosed garden-sites, framed spaces will reemerge with a salubrious density, both interior and exterior, publicly as well as privately. Volumetric space modules of 300 to 500 square-meters can redefine clear sub-urban quarters as a conceptual ordering with hypaethral 'thinkmodules' [14] within 'tightness and lightness', and at the same time transform the whole site to a mini mundus of private space. Ultimately and immanently these urban win-win dimensions add a surplus value for both urban as well as building economy and ecology.

Everything is space - space is everything. 'Open-plan' arrangements and openness onto surrounding patios permanently allow for neutrality in terms of circulation and functional dispositions. The individual withdraws into flexibly constructed zones. Unobstructed openness surrounding serving cores expands into private garden-patios and converts exterior space into enlarged living space.

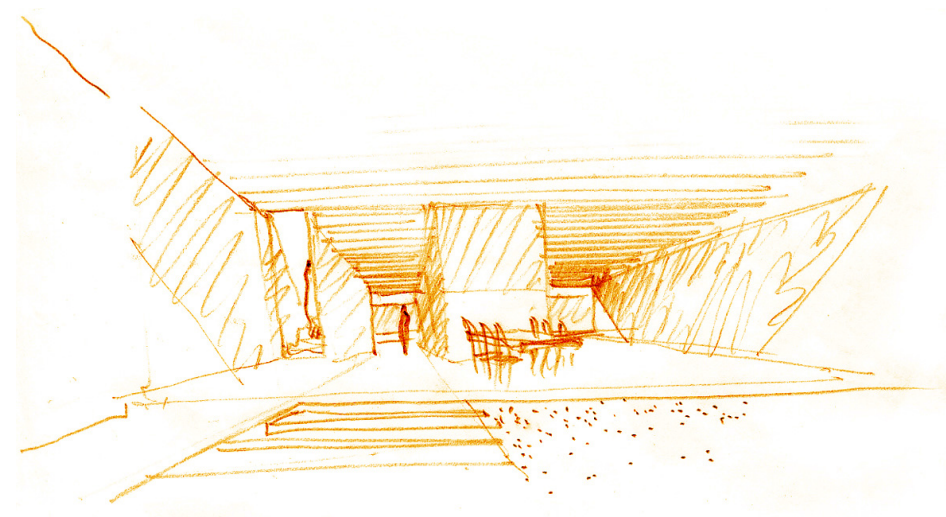

Figure 13: 'New Urban-Garden-Houses', Interior Sketch, 'Urban Modules', Osnabrueck, Germany 2004 - 2005 [Author] 


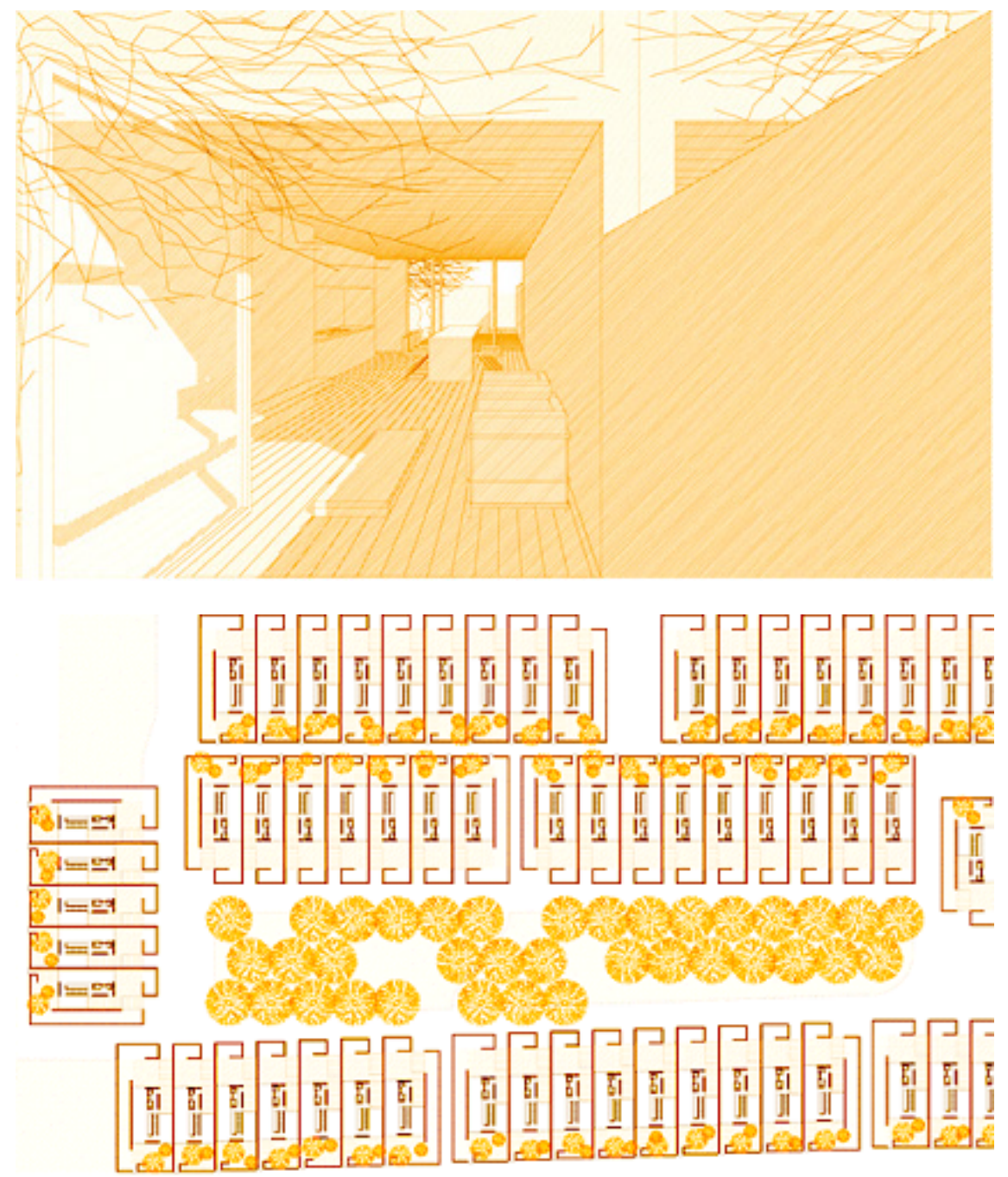

Figure 14: Ideal Plan and Space 'Quarter + Place = Tight + Light', LBS Award [14] 'New Urban-Garden-Houses', Osnabrueck, Germany 2004 - 2005 [Göritz + Despang Architekten]

'The garden is the house is the garden...' and 'the city is the house is the city...' - both clarify the ambivalent oscillation between vegetation and architecture, interior and exterior, private sphere and public sphere, individual and society, micro- and macrocosm of this think-module. 
Nowhere else is the interaction between concretely defined frameworks and openly defined free spaces more potent than in a society's dwelling-concepts. Exactly at this point a balance is required concerning the eternal dialectics of freedom and ligature, of the society and the individual. However, if we renunce of this difficult professional resolution, we are left with a fatal trivialization: the 'Qualities of Shape' are gone - long live the 'Statutes of Styling'.
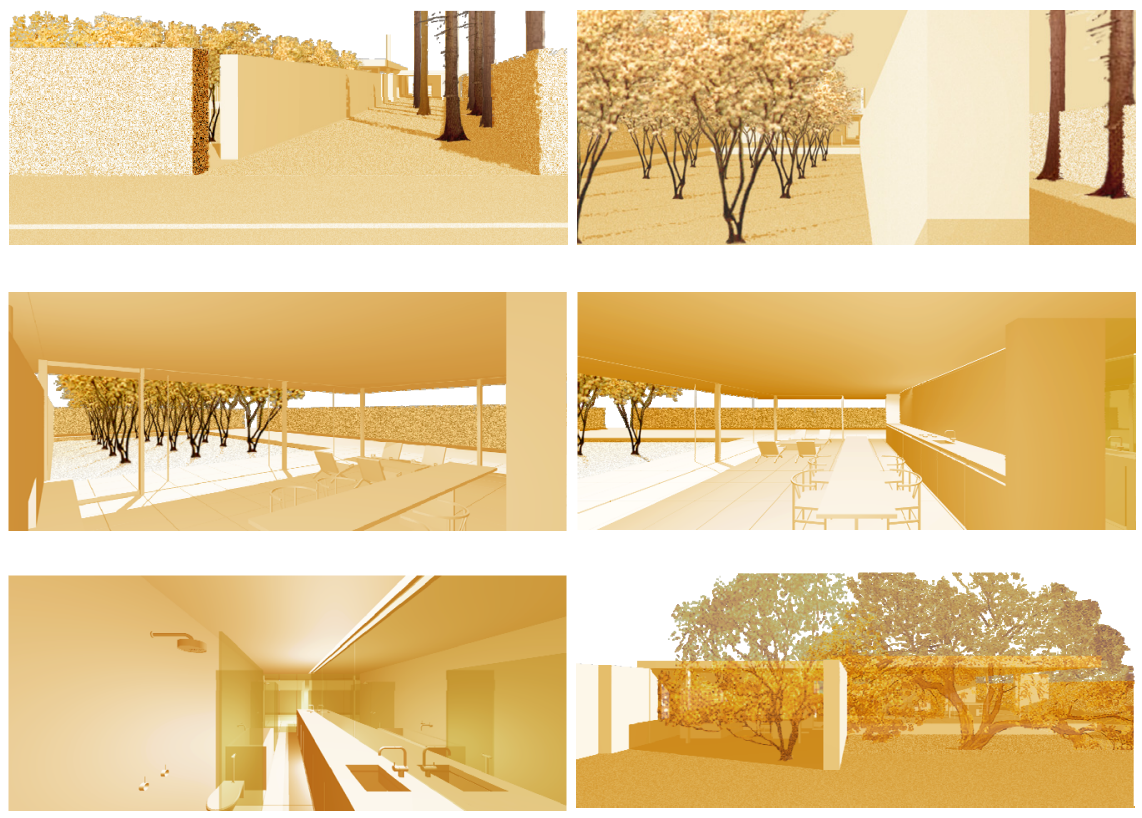

Figure 15: 'A House is a Garden is a House...' Spacial Sequences, Isernhagen, Germany 2005 - 2006 [Author]

\section{Conclusions: involuntary peculiarities}

Rare masterpieces of extra-ordinarily well conceived settlings and dwellings reveal nothing but the missing of common sense. Thus they become involuntary peculiarities in this genre that indicate nothing but a dissent. Prototypical dwelling- and think-modules that set an example for professional reformation only succeed if the intentions are shared mutually, by society at first, and consequently by client and architect: Azumas and Ando [7], Pahdes and Bienefeld [15], Neuendorfs and Pawson [16]. Or fail if the intentions are not shared: Madame Savoye and Corbusier [17], Mrs Farnsworth and Mies [18]. Often such commonality succeeds only in solitary personal union: Utzon with his Can Lis [19], Barragàn as his own client, Corbusier with his Cabanon [20]. 
Teacher and surveyor Thoreau too had built his cabin himself. At that time an unregarded magnificence still characterized this craft: it took the concrete world under one's feet and translated into exact planimetry. This translation necessitated fundamental perception of the given, precision in its mapping, abstraction with regard to the topos. A remarkably abstract interpretation of and response to physical conditions.

Topography or biography - even the transfer of a 'life-cadastre' would be the interpretation of one's own landmarks. A value system could emerge from the benefits of such an identification; however, this value system is always bound up in the context of a greater topography. The totality of the individual prohibits exactly this translation as it is required for collecting a common canon of works towards essential dwelling that then add to a collective society.

Superior frameworks are generally regarded as infantilization, omission of the redundant as withdrawal of the personal. Consensus and consistence are thus hardly achievable, and consequently no conventions can be derived, or so is the common assumption. This separation first and foremost makes the few lived works exceptions from trivial norma, and thus they become involuntary, unintentional manifestos of dwelling.

'How do we achieve true liberty?', he was willing to explore. Thoreau's Walden remains relevant. 'What is the use of a house if you haven't got a tolerable planet to put it on?', he had asked himself and us [3]. Apparently, questions like these drive some to isolate themselves as hermits. Occasionally even architects are in their number, but inhabitants and users far more seldom. The basic dissent remains.

The deal of a 'New Convention' remains missing. Apparently we are pretending that 'sustainability' can be achieved despite the lacking of such essential prerequisites for the enduring. Meanwhile helpless historicist and techno-stylistic games of contemporary design leave their signatures. How shall we relate what has no tongue...? We have to restart at our inherited sophistication and tell the story anew: like in any other case, this can only be solved by educating a dwelling society, rather than by just focusing on academic and professional intelligentsia.

\section{References}

[1] Berger, Alan, 'Drosscape: Wasting Land in Urban America', Princeton Architectural Press: New York, 2006

[2] Thoreau, Henry David, 'Walden; or, Life in the Woods', Ticknor and Fields: Boston, 1854

[3] IKEA, 'Wohnst Du noch oder lebst Du schon? ' / 'Are you just existing somewhere or have you made a home? ', Toytown Germany - Discussion Forum - Germany-wide - Translations www.toytowngermany.com/lofi/index.php/t113764.html

[4] Laugier, Marc Antoine, 'Essai sur l'architecture', 1753 French, 1755 English, Encyclopaedia Britannica 
[5] Nakahara, Kimiyo [Editor], 'Interior Design Uchida, Mitsuhashi \& Studio 80', Taco: Berlin, 1988

[6] Ito, Toyoo, 'From Visual Space to Acoustic Space - The Interiors of Shigeru Uchida', in [5] pp 8 - 9

[7] 'Tadao Ando', Academy Editions: London / St Martin's Press: New York / Artemis: Zürich, 1990, pp 18 - 21

[8] AA.VV., 'Tadao Ando: Breathing Geometry', 9H Gallery, London 1986

[9] Lesson, Shaker: 'Don't make something unless it is both necessary and useful. But if it is both necessary and useful, don't hesitate to make it beautiful', $19^{\text {th }}$ century

[10] Katsura Imperial Villa: detached palace with associated gardens, Kyoto, Japan, 1615

[11] Ando, Tadao, 'Representation and Abstraction'. The Japan Architect: International Edition of Shinkenchiku, 322, p 8, April 1988

[12] Blaser, Werner, 'Mies van der Rohe, Die Kunst der Struktur', Artemis, Zürich: 1965, pp $38-49$

[13] Weston, Richard, 'Utzon', Nieswand: Kiel, 2001, pp 84 - 111

[14] LBS architecture competition 'Im Zentrum zu Hause' on 'Stadthäuser', 'New Urban Garden Houses', $2^{\text {nd }}$ prize [author in associated collaboration], Werkgemeinschaft Despang + Göritz www.bauwelt.de/arch/bauwelt/wettbewerbe/entscheidungen_detail.php?wb_ id $=183326$

[15]'Atriumhaus in Rodenkirchen / Architekt Heinz Bienefeld', Baumeister: München, 4/1981, pp 365 - 367

[16]'JohnPawson, Monographs on Contemporary Design', Editorial Gustavo Gili: Barcelona, 1992, pp 16 - 23

[17] Benton, Tim, 'Les Villas de Le Corbusier 1920 - 1930', Sers, Philippe: Paris, 1984, pp $191-207$

[18] Frampton, Kenneth, 'American Masterworks, The Twentieth Century House', Rizzoli: New York, 1995, pp 102 - 109

[19] Norberg-Schulz, Christian, 'Jørn Utzon and the Primordial', arkitektur DK, Arkitektens Forlag: København, 2 1996, pp 73 - 95

[20]'Barragan, Obra Completa', Colegio de Arquitectos de la Ciudad de Mexico, Tanais Ediciones: Sevilla / Madrid: 1995

[21] Boesiger, Willy [Editor], 'Le Corbusier', Artemis, Zürich: 1972, pp 94 - 97 